\title{
PENDAMPINGAN IMPLEMANTASI MEDIA PEMBELAJARAN INOVATIF DI SMP NEGERI 2 DAMPIT KABUPATEN MALANG
}

\author{
Agus Purnomo \\ agus.purnomo.fis@um.ac.id \\ Prodi Pendidikan IPS, Fakultas IImu Sosial, Universitas Negeri Malang \\ Diterima 22 Oktober 2018, dipublikasikan 30 April 2020
}

\begin{abstract}
Abstrak
SMP Negeri 2 Dampit pernah mendapatkan pendampingan dari Universitas Brawijaya untuk membuat media pembelajaran menggunakan Power Point. Banyak manfaat yang dirasakan oleh guru di sekolah tersebut adalah mereka mampu untuk menyajikan bahan ajar menggunakan perangkat lunak Microsoft Office Power Point yang dilengkapi dengan link. Namun setahun setelah pelaksanaan perlu ada penyegaran dan pembaruan tentang bagaimana cara menggunakan media pembelajaran yang inovatif. Untuk itu direncanakan penyegaran media pembelajaran pada $M S$ Power Point dilakukan 1 kali pertemuan, dan pembaruan media FlipBook Maker serta Prezi dilakukan 1 kali pertemuan. Total rencana dari kegiatan pendampingan ini adalah 2 kali pertemuan di sekolah mitra. Instrumen yang digunakan mencakup modul petunjuk, laptop, proyektor, dan mini wifi. Hasil yang didapatkan adalah (1) Menyegarkan kembali kemampuan untuk membuat media menggunakan MS Power Point menggunakan hyperlink. Sebelumnya guru-guru di SMP N 2 Dampit sudah mendapatkan pelatihan dari Universitas Bawijaya, (2) Mendapatkan pemahaman baru dalam menyajikan materi dengan menggunakan media FlipBook Maker. Media yang sebelumnya dibuat menggunakan MS Power Point merupakan bahan dasar sebagai media FlipBook Maker, dan (3) Mendapatkan pemahaman baru dalam menyajikan materi dengan menggunakan media prezzi. Pada dasarnya prezzi merupakan media untuk bahan tayang yang sama dengan MS Power Point, hanya saja dalam media ini sudah terdapat template yang siap untuk digunakan dengan animasi yang lebih menarik.
\end{abstract}

Kata Kunci: Media Inovatif, MS Power Point, FlipBook Maker, Preezi

\section{PENDAHULUAN}

Penjabaran dari UU No. 20 tahun 2003 tentang sistem pendidikan nasional, mendasarkan pada profesionalisme guru, yaitu standar kompetensi yang harus dikuasai seorang pendidik (guru). Dijelaskan, standar kompetensi yang harus dimiliki guru mencakup empat jenis kompetensi yaitu: kompetensi pedagogik, kepribadian, profesional, dan sosial. (1) Kompetensi pedagogik adalah kemampuan mengelola pembelajaran yang meliputi pemahaman peserta didik, perancangan dan pelaksanaan pembelajaran, evaluasi hasil belajar, dan pengembangan peserta didik untuk mengaktualisasikan berbagai potensi yang dimilikinya. (2) Kompetensi kepribadian adalah kemampuan kepribadian yang mantap, stabil, dewasa, arif dan berwibawa, menjadi teladan peserta didik, dan berakhlak mulia. (3) Kompetensi professional adalah kemampuan penguasaan materi pembelajaran secara luas dan mendalam, yang memungkinkannya membimbing peserta didik memenuhi standar kompetensi yang ditetapkan dalam standar nasional pendidikan. (4) Kompetensi sosial adalah kemampuan pendidik sebagai bagian dari masyarakat untuk berkomunikasi dan bergaul secara efektif dengan peserta didik, sesama pendidik, tenaga kependidikan, orang tua/wali peserta didik, dan masyarakat sekitar (Dirjen Dikti, 2005). Persyaratan kompetensi guru tersebut dibuktikan dengan sertifikat pendidik yang diperoleh melalui sertifikasi.

Sertifikasi guru dalam jabatan telah berlangsung sejak tahun 2006. Sejak tahun 2006, banyak perubahan yang terjadi dalam dunia pendidikan. Dagget (1992) mengatakan bahwa dunia tempat anak kita tinggal nanti akan berubah empat kali lebih cepat dari pada sekolah. Faktor penyebabnya adalah karena perkembangan teknologi. Oleh karena itu dunia pendidikan juga harus menysuaikan laju perkembangan itu dan mengaplikasikannya dalam pembelajaran. 
Tahun 2015 SMP N 2 Dampit mendapatkan pendampingan dari Universitas Brawijaya untuk membuat media pembelajaran menggunakan Power Point. Manfaat yang dirasakan oleh guru di sekolah tersebut adalah mereka mampu untuk menyajikan bahan ajar menggunakan perangkat lunak Microsoft Office Power Point yang dilengkapi dengan link (akses tautan). Setahun setelah proses pendampingan tersebut banyak kemampuan untuk memanfaatkan media pembelajaran yang sudah mulai dilupakan (Sinyamin. 2017).

Melihat kenyataan yang diuraikan di atas, tampaknya perlu dilakukan suatu kegiatan yang mampu menyegarkan kembali pemahaman dan keterampilan para guru dalam mengembangkan profesionalismenya, khususnya dalam pengembangan media pembelajaran inovatif. Hal ini akan dilakukan melalui kegiatan pengabdian pada masyarakat (P2M) sebagai salah satu kegiatan Tri Dharma Perguruan Tinggi yang mutlak dilakukan oleh dosen.

Kegiatan P2M ini akan dilakukan di Kecamatan Dampit Kabupaten Malang. Khalayak yang menjadi sasaran kegiatan ini adalah para guru SMP N 2 Dampit. Kegiatan ini berupa penyegaran dan pembaruan menganai media pembelajaran inovatif. Kegiatan P2M yang diusulkan ini menekankan pada kemampuan dan keterampilan para guru dalam mengimplementasikan bahan ajar yang sudah ada pada media pembelajaran inovatif yang akan dibuat. Media pembelajaran inovatif yang akan dikenalkan kembali adala MS Power point. Untuk media pembalajaran inovatif yang akan dikenalkan adalah FlipBook Maker dan Prezi.

SMP N 2 Dampit berada di Kecamatan Dampit Kabupaten Malangyang berjarak $40 \mathrm{~km}$ dengan Kota Malang. Total terdapat 26 guru di sekolah tersebut. Program pengingkatan kualitas sumberdaya manusia terakhir yang didapatkan oleh instansi tersebut pada tahun 2015 dari Universitas Brawijaya Malang dengan kegiatan pelatihan MS Power Point sebagai media pembelajaran dan tidak mendapatkan tindak lanjut kembali. Oleh karena itu perlu ada penyegaran dan pembaruan kembali pada kompetensi pedagogik yang dimiliki oleh guru di SMP N 2 Dampit.

Penggunaan perangkat elektronik pada media pembelajaran yang akan di kenalkan bertujuan untuk mengenalkan kepada guru dan siswa bahwa dunia pembelajaran sekarang memasuki tahap keempat (Sayono. 2016). Tahap pertama pembelajaran hanya bersumber dari satu orang (Tahap Fulusuf dan ilmuan). Kemudian seiring dengan berkembangnya teknologi cetak yang mampu menghasilkan buku muncul tahap Ensiklopedi (sebuah buku yang memuat berbagai macam informasi). Tahap berikutnya setelah tercipta teknologi digital disebut dengan tahap Encarta. Tahap Encarta disebut dengan tahap mengubah bentuk cetak ensiklopedi menjadi bentuk digital. Seluruh tahap yang ada merupakan tahap pembelajaran yang berpusat pada guru karena laju informasi hanya berlangsung satu arah. Namun setelah diciptakannya mesin pencari di dunia maya muncul yang namanya tahap Wikipedia, tahap yang memungkinkan untuk laju informasi berjalan 2 arah untuk saling melengkapi.

\section{METODE}

Masalah yang dialami oleh guru SMP Negeri 2 Dampit adalah kemampuan dalam mengolah media pembelajaran inovatif berbasis teknologi sudah mulai memudar. Padahal beberapa guru mengaku kemampuan mengolah bahan ajar dalam media sangat membantu dalam penyampaian materi di kelas. Oleh karena itu untuk mengatasi masalah tersebut perlu ada pendampingan dan penyegaran kembali mengenai kompetensi pedagogik dalam menggunakan atau merancang media pembelajaran inovatif. Penyegaran media pembelajaran pada MS Power Point dilakukan 1 kali pertemuan, dan pembaruan media FlipBook Maker serta Prezi dilakukan 1 kali pertemuan. Total rencana dari kegiatan pendampingan ini adalah 2 kali pertemuan.

Kegiatan pendampingan media pembelajaran inovatif ini dilakukan dengan langkah-langkah sebagai berikut.

1. Berkoordinasi dengan guru SMP Negeri 2 Dampit

Penulis berkoordinasi dengan SMP Negeri 2 Dampit berkaitan dengan kegiatan pelatihan, terutama mengenai tempat dan jadwal pelaksanaan, serta perlengkapan dan bahan yang harus dipersiapkan peserta sebelum mengikuti kegiatan pelatihan seperti perangkat komputer atau laptop.

2. Penyegaran MS Power Point

Tahap ini menyegarkan kembali pengetahuan untuk merancang media pembelajaran menggunakan MS Power Point dengan menggunakan link (tautan). Prosesnya yang cukup sulit menjadi pertimbangan untuk mengalokasikan 1 kali pertemuan dalam proses pendampingan. Tahap ini peserta akan mendapatkan modul sederhana yang dapat dijadikan panduan selama pendampingan. 
Modul Penyegaran MS POWER POINT

Bapak tbu garu SMP N 2 Dampit yang ferhormat, berikut adalah panduan untuk membuat media pembelajarun dulam M/S Pover Point dengan tïnk (tuuian). Yang dimaksudkan dengan tualan adalah kerdapat akses untuk menuju file, data. gambar, dan/atau grafik yane dimaksudkan untuk mempercepat proses penjelasan. Tuutan dupat ditunjukkan dengan kata-kats jelas seperti KLIK DISINI atau dengan CEKIDOT (Check // Owe) untuk membuka tautan. Tautan juga dapat ditunjukkan dengan simbol abstrak atuu pictorial yang dapat dipahami olch pengguna seperti 1 (home) untuk kembali ke menu utama.

Bapuk Ibu garu dapat menggunakan file MS Fonver Point yang sudah dibuat sebelumnya untuk membual medin ini stau membuat file yang baru. Setelah file konten felah siap dan disusun sesuai dengan urutan penyajiannya maka barulah tautan dapat diatur. Misal file yang tersaji memiliki 10 lembur dengan isi teks, gambar, dan diagram.

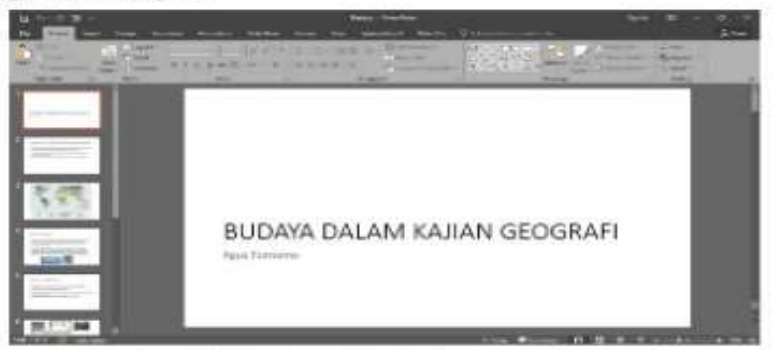

Gambar 1. File MS Power Point Hudaya dalam Kajian Goografi

Jika penyajian secara manaal dari lembar ke lembar dirasakan kurang menarik atau tidak memudahkan karena beberapa konten memiliki keterkaitan dengan lembar ke-n atas lembar sebelumnya maka Anda dupat mengeunakan

Gambar 1. Modul Penyegaran MS Power Point

3. Pembaruan Media Inovatif

Pertemuan berikutnya peserta pengabdian dikenalkan untuk membuat media pembelajaran dengan menggunakan FlipBook Maker dan Prezi. Tujuan mengenalkan media lain adalah untuk memberikan wawasan baru atau sudut pandang baru kepada guru dalam mengajar sehingga dapat membawa suasana baru dalam pembelajaran. Pada pertemuan ini peserta juga akan mendapatkan modul sederhana untuk mempermudah dalam mempraktikkannya.

LAMPIRAN Pembarua!

reiplloneh Maker

Hapak the guru SMP N 2 bampit yang terhomat. Ada eara tain untuk mengemas media yang sutah Anda buar menjadi bentuk dipizat dan lebih menarik Caranya dengan mengutah farmatnya menjadi bula digital (digeinat beod) menggunakae perangkat lanak Fliphoot Mader.

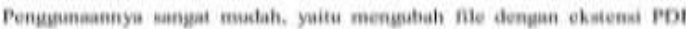

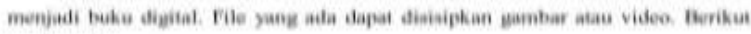
panduannya.

Pertama boka perangkat lianak Fliphosud Moder

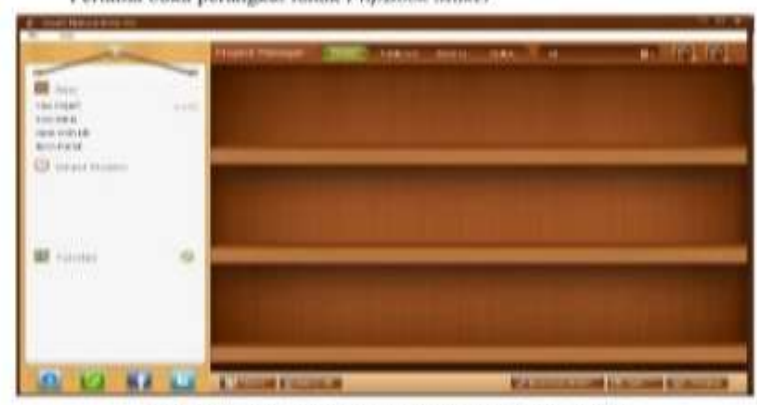

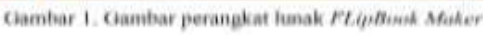

Langkah yang dipertukan sangat sedertana. yaitu eukup dengan membuat projek baru (new prriesy) dan pilih Nile Por, gambar, atau video yang akan

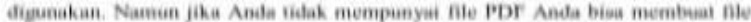

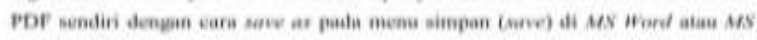
Power Molet. 


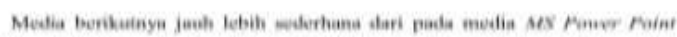

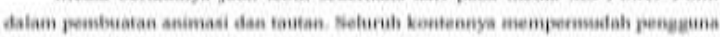

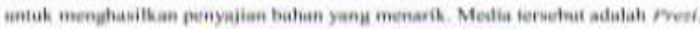

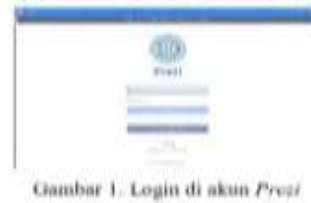

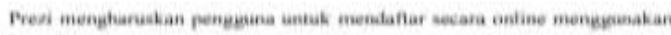

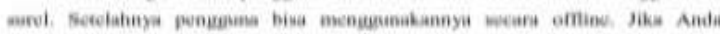
teriobueg dengan internet maka pres yang tersedia bisa Anda unduh dan Anda

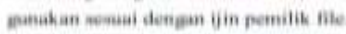

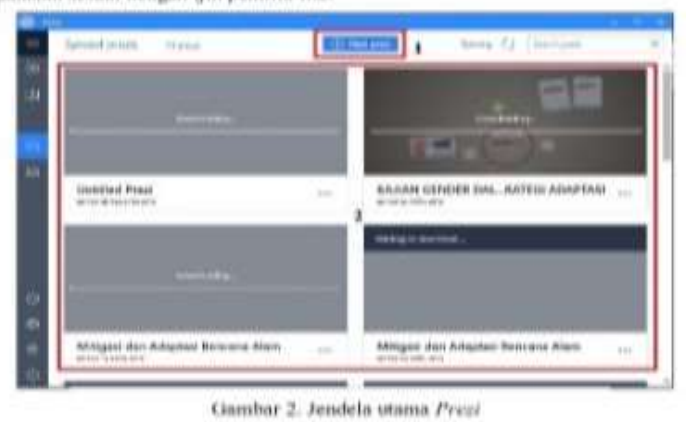

Gambar 2. Modul Flipbook Maker dan Prezi

\section{HASIL DAN PEMBAHASAN}

Pelaksanaan pengabdian berlangsung pada hari senin-selasa tanggal 15-16 Mei 2017 dengan jadwal dari pukul 13.00-16.00 WIB. Peserta yang ikut kegiatan pelatihan ini sebanyak 26 Guru SMP N 2 Dampit. Kegiatan ini berupa penyampaian materi dan praktek langsung untuk penggunaan media pembelajaran menggunakan MS Power Point, FlipBook Maker, dan Prezzi. Terdapat 4 mahasiswa yang membantu pelaksanaannya sebagai pendamping kelompok kecil yang beranggotakan 6-7 orang. Setiap kelompok langsung mempraktikkan cara penggunaan media setelah mendapatkan materi oleh tim instruktur.

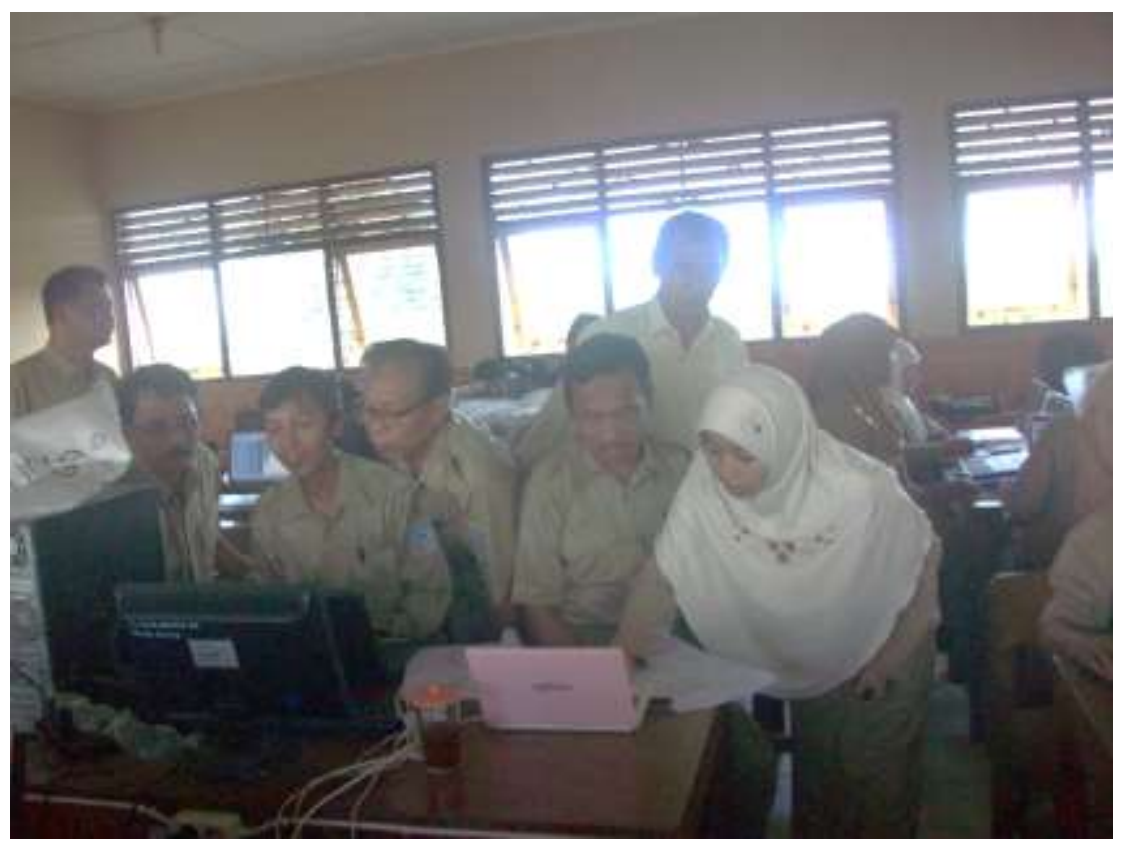

Gambar 3. Guru yang mempraktekkan materi yang sudah didapatkan

Berdasarkan wawancara, tanya jawab dan pengamatan langsung selama kegiatan berlangsung, kegiatan pengabdian pada masyarakat ini memberikan hasil sebagai berikut: 
1. Menyegarkan kembali kemampuan untuk membuat media menggunakan MS Power Point menggunakan hyperlink. Sebelumnya guru-guru di SMP Negeri 2 Dampit sudah mendapatkan pelatihan dari Universitas Bawijaya.

2. Mendapatkan pemahaman baru dalam menyajikan materi dengan menggunakan media FlipBook Maker. Media yang sebelumnya dibuat menggunakan MS Power Point merupakan bahan dasar sebagai media FlipBook Maker.

3. Mendapatkan pemahaman baru dalam menyajikan materi dengan menggunakan media prezzi. Pada dasarnya prezzi merupakan media untuk bahan tayang yang sama dengan MS Power Point, hanya saja dalam media ini sudah terdapat template yang siap untuk digunakan dengan animasi yang lebih menarik.

Faktor yang mendukung terlaksananya kegiatan pengabdian pada masyarakat ini adalah besarnya minat dan antusiasme peserta selama kegiatan, sehingga kegiatan berlangsung dengan lancar dan efektif. Sedangkan faktor penghambatnya adalah keterbatasan waktu serta masih kurangnya fasilitas berupa jaringan internet. Pihak sekolah sudah mengupayakan kepada pihak desa setempat namun masih belum mendapatkan tanggapan.

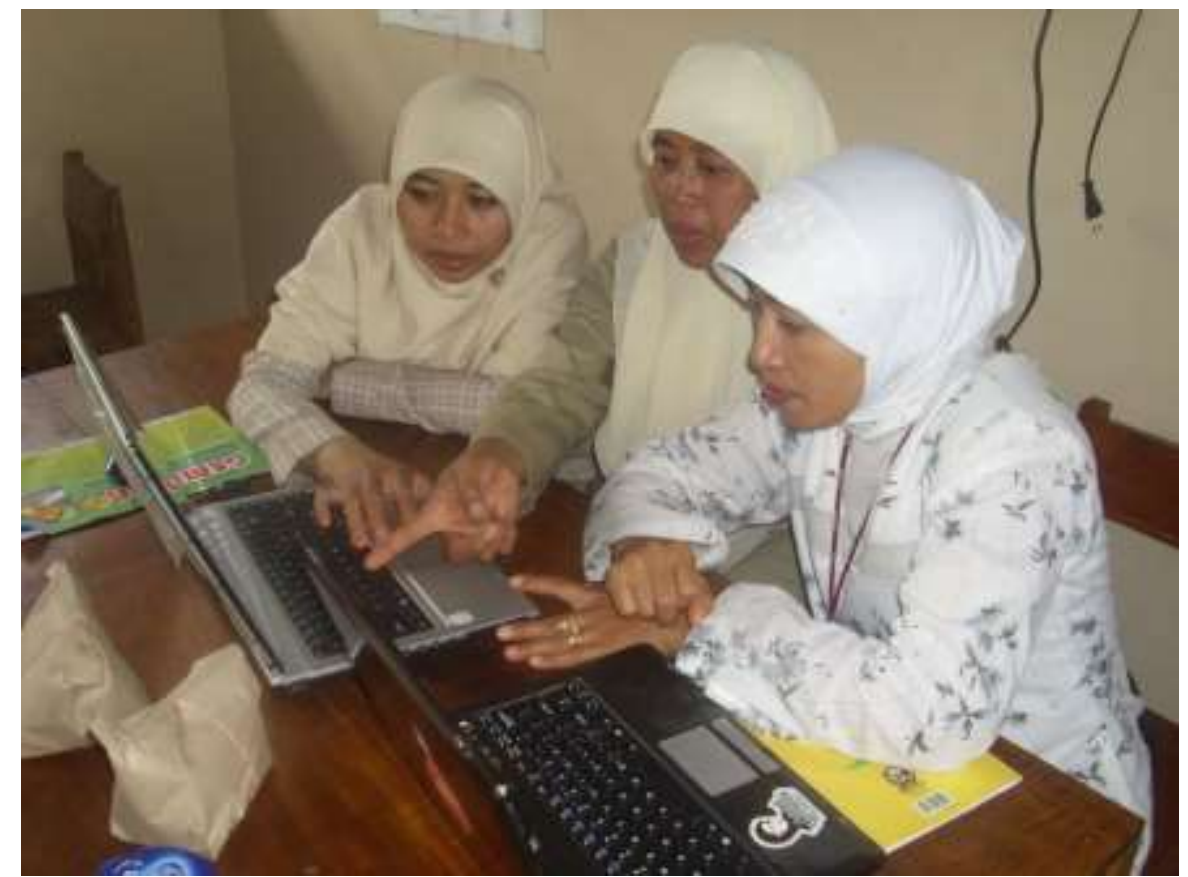

Gambar 4. Guru yang mempraktekkan materi yang sudah didapatkan

\section{SIMPULAN}

Dari kegiatan pengabdian kepada masyarakat ini dapat disimpulkan bahwa pengetahuan dan pemahaman guru SMP Negeri 2 Dampit dalam membuat media menjadi meningkat dengan semakin ahli dalam menggunakan MS Power Point dan dapat menggunakan media baru berupa FlipBook Maker dan Prezzi.

Mengingat besarnya manfaat dari kegiatan pengabdian kepada masyarakat ini, maka selanjutnya perlu kegiatan serupa yang berkesinambungan untuk menjembatani informasi dan pengetahuan dari pendidikan tinggi ke pelaksana pendidikan dasar dan menengah di lapangan sebagai kegiatan penyegaran atau memperbarui pengetahuan yang ada tentang pembelajaran.

\section{DAFTAR PUSTAKA}

Dirjen Dikti. 2005. Pedoman Umum: Pengembangan Sistem Asesmen Berbasis Kompetensi. Jakarta: Depdiknas.

Dagget. Willard. 1992. Job Skills of the '90s Requires New Education Model for ALL Student.

Sinyamin. 2017. Hasil wawancara pada tanggal 10 Januari 2017. Di SMP Negeri 2 Dampit Kabupaten Malang.

Suyono, Djoko. 2016. Pelatihan PEKERTI Universitas Negeri Malang. Universitas Negeri Malang. 